\title{
Do Clonal and Bud Bank Traits Vary in Correspondence with Soil Properties and Resource Acquisition Strategies? Patterns in Alpine Communities in the Scandian Mountains
}

\author{
Graciela M. Rusch • Bodil Wilmann • \\ Jitka Klimešová • Marianne Evju
}

(C) The Author(s) 2010. This article is published with open access at Springerlink.com

\begin{abstract}
Plant traits associated with resource acquisition strategies (specific leaf area (SLA), leaf dry matter content (LDMC), leaf size and plant height) change along gradients of soil properties, being the most conservative in a resource-poor environment and the most dynamic in a resource-rich environment. Clonal attributes also vary along soil and other environmental conditions. We hypothesized that in alpine communities in the Scandian Mts. (1) the average composition of traits in a plant assemblage in terms of $i$ ) the predominance of different clonal growth organ types, $i$ ) the number of buds in the bud bank, iii) the distribution of the bud-bank (above- and below ground), $i v$ ) the distance of lateral spread and $v$ ) the longevity of plant - offspring connections would change along a gradient of soil properties and (2) that this variation would be in correspondence with that of traits associated with resource acquisition strategies (SLA, LDMC, leaf size and plant height). Analysis of clonal and bud bank traits for species of alpine communities supported our first hypothesis: with decreasing soil quality the most common clonal growth organs were rhizomes, and there was a predominance of perennial bud banks located at the soil surface or below-ground, low rates of lateral spread and long persistence of plant - offspring connections. Our second hypothesis was partly supported. As predicted, at the level of the plant assemblage, these clonal and bud bank traits were positively associated with LDMC, and negatively with leaf size and plant height. These observations reinforce the hypotheses about trade-offs between acquisition and retention strategies in plants. The only result that was in contradiction with our expectations was the lack of correspondence between clonal and bud bank traits and SLA that could be attributed to errors associated to
\end{abstract}

G. M. Rusch $(\bowtie) \cdot$ B. Wilmann $\cdot$ M. Evju

Norwegian Institute for Nature Research (NINA), Gaustadalléen 21, NO-0349 Oslo, Norway e-mail: graciela.rusch@nina.no 
the measurement of the area of narrow and small leaves or to the dependence of the SLA index on species-specific morphological attributes.

Keywords Alpine plant communities · Assemblage average traits ·

Environmental gradients · Norway

Plant nomenclature Lid and Lid (2005)

\section{Introduction}

In the past decade, a comprehensive work on eco-physiological attributes of plants has identified a series of functional traits, i.e., attributes that are related to plant responses to environmental factors and that have an effect on functions of ecosystems and biomes (conf. Cornelissen et al. 2003). Some of these traits are fair predictors of plant performance (Kazakou et al. 2006), competitive ability (Grime et al. 1997) and tolerance to environmental harshness (Wright and Westoby 1999). There is also the understanding that these traits correspond to adaptations of plants along gradients of resource availability, and that are related to acquisition and retention strategies (Grime et al. 1997). Numerous studies have concentrated on leaf traits, such as specific leaf area (SLA), leaf dry matter content (LDMC) and leaf area (e.g., Reich et al. 1992, 1999; Ryser and Urbas 2000), and substantial evidence at the level of species supports a correspondence between these traits and the level of resource availability. Under favorable conditions for growth, plants have strategies that allow high rates of resource-acquisition and growth, which are in turn associated with high SLA and leaf area, and low LDMC.

There is also evidence of a correspondence between levels of resource availability and traits that are related to clonal growth and vegetative regeneration (e.g., Sammul et al. 2003), but these relationships have been less examined (Klimešová and de Bello 2009). Clonal growth forms are distributed unevenly along environmental gradients, and the patterns observed appear to be irrespective of the species phylogeny, which provides a basis for further extending functional theories to explain trait-environment relationships (van Groenendael et al. 1996). For example, stem-derived clonal structures seem to be more common under nutrient-rich conditions and under low-light intensities than structures derived from roots, as are the capacity to spread and the short longevity of the connection between the parent plant and the vegetative off-spring (van Groenendael et al. 1996). There is also evidence that the tendency of increasing vegetative spread and early splitting of ramet systems is more frequent under nutrient-rich, shaded (van Groenendael et al. 1996; Sammul et al. 2003) and more mesic conditions (Halassy et al. 2005), whereas structures of tightly packed and/or integrated ramets occur more commonly under nutrient-poor (van Groenendael et al. 1996; Jónsdóttir and Watson 1997) and dry conditions (Halassy et al. 2005; Klimeš 2008).

The bud bank, i.e., the population of dormant meristems (Harper 1977), is an important determinant of the capacity of a plant to re-sprout in seasonal climates and after disturbance (Klimešová and Klimeš 2007). However, also in this case, it appears to be the interplay between plant traits and the abiotic environment that 
determines the potential role of below-ground bud banks. Across a regional gradient, the abundance of bud banks increased with average annual precipitation (de Bello et al. 2005; Dalgleish and Hartnett 2006) and there are indications that the meristem limitation can represent an important constraint for plant growth responses to environmental variability.

Traits that show a correspondence with the capacity of the plant to take up resources and grow have a linkage to the strategies of plants to re-sprout and restore tissues (Bellingham and Sparrow 2000). The expression of these relationships results from an interaction with the level of resource availability (Ferraro and Oesterheld 2002; Wise and Abrahamson 2005). For example, high tissue turnover and resource acquisition rates are important strategies for plants with high growth rates (del-Val and Crawley 2005) and occurring at high resource availability (Grime et al. 1997).

This study deals with two main questions. First, it addresses the hypothesis that there is a correspondence between the distribution of plant clonal and bud bank traits and a gradient determined by soil properties at a local scale in alpine communities in the Scandian mountains. In accordance with current notions, we hypothesized that the average composition of traits in a plant assemblage in terms of: $i$ ) the predominance of different clonal growth organ types, $i i)$ the number of buds in the bud bank and iii) its readiness to be activated (i.e., meristems on shoots and distributed above ground or close to the soil surface), iv) the distance of lateral spread, would increase and $v$ ) the longevity of plant - offspring connections would decrease with better soil conditions. Second, following the predictions about plant functional specializations along resource availability gradients we hypothesized a correspondence between the average composition of traits generally associated with high relative growth rates (SLA, LDMC, leaf size) and competitive ability (plant height) (Grime et al. 1997) and the composition of clonal and bud bank traits (van Groenendael et al. 1996; Halassy et al. 2005).

\section{Methods}

\section{Study Area}

The study was conducted in an area of ca. $200 \mathrm{~km}^{2}$ in the alpine zone, i.e., above the treeline, between $900-1,100 \mathrm{~m}$ a.s.l. in the central Scandian mountains (UTM coordinates: Map datum WGS 84, Zone 32 V, P 07600, Q 51300 for Berghøgda and P 04600, Q 636960 for Båttjønndalen). Mean annual temperature (Berkåk, Norwegian Meteorological Institute, corrected for height differences $\left.\left(-0.6^{\circ} \mathrm{C} / 100 \mathrm{~m}\right)\right)$ is $0.65^{\circ} \mathrm{C}$, with $10^{\circ} \mathrm{C}$ and $-8^{\circ} \mathrm{C}$ as mean temperature of the warmest month (July) and coldest month (January), respectively. Precipitation is evenly distributed throughout the year, with a yearly average of $750 \mathrm{~mm}(1970-2005)$.

The area is dominated by lichen heath (Cladonia spp., Cetraria spp., ca. 80\% cover). Other heath formations with dominance of shrubs (Betula nana, Empetrum nigrum subsp. hermaphroditum and Vaccinium myrtillus) cover ca. $10 \%$ of the area, and snow-beds, alpine meadows and willow thickets cover approximately $8 \%$ of the area (Rusch et al. 2003). This study was confined to snow-beds, dominated by Salix herbaceae, and alpine meadows, dominated by graminoids and forbs (i.e. 
Deschampsia cespitosa, Avenella flexuosa, Carex bigelowii, Alchemilla alpina, Viola biflora and Omalotheca supina).

\section{Study Sites}

Data on vegetation and soil properties were collected in 16 sites located on snow-bed communities and meadows, and distributed in the two areas, Berghøgda (nine sites) and Båttjønndalen (seven sites). In terms of topography and landscape forms, altitude and land-use, the two areas are representative of the central region of Sør-Trøndelag. They were selected through inspection of topographic maps and in cooperation with the local farmers to perform a series of long-term studies. There were a priori no indications of differences between the areas. Distances between sites within an area ranged between 65 and 1,489 $\mathrm{m}$ and in both areas, sites were located within a similar altitudinal range. A $50 \times 50 \mathrm{~m}$ sampling site was demarcated and sub-divided into a grid of $5 \times 5 \mathrm{~m}$ plots, which were the units for the vegetation composition records. The line of plots along the borders was left as a buffer area and 64 plots were included in the site analyses except for Berg 4 (63 plots), Berg 6 (33 plots) and Bat 9 (100 plots).

Site species composition was determined through visual estimates of the cover of vascular plant species in the $5 \times 5 \mathrm{~m}$ plots and averaged for the site. Unidentified species had in all occasions $<1 \%$ of the site cover except once $(1.6 \%$ Carex spp. $(C$. bigelowii or $C$. nigra)). Species considered as species sections were Hieracium alpinum coll. and Taraxacum croceum coll. A total of 111 species were included in the dataset (Appendix 1).

\section{Site Soil Properties}

Soil physical and chemical properties were assessed from 10 topsoil $(0-5 \mathrm{~cm})$ samples per site taken with a 22-mm diameter soil corer and lumped into one composite sample per site. The analyses were conducted at "Laboratoire d'Analyses des Sols" of the National Institute for Agronomic Research (INRA, 62000 Arras, France) using French standards (Afnor 1994) according to the following protocols: $\mathrm{pH}$ was measured in a water-filtrate suspension with a mass-to-volume ratio of 1:2.5 (NF ISO 10390). Organic C content was determined by oxidation with potassium dichromate and sulphuric acid (NF ISO 14235). Total organic nitrogen content was determined by the Kjeldahl method (NF ISO 11261). Total soil P content was determined by ICP following calcination at $450^{\circ} \mathrm{C}$ and wet-digestion by $\mathrm{HF}$ and $\mathrm{HClO}_{4}^{-}$of soil (NF X 31-147): P concentrations were measured by ICP. Cation Exchange Capacity (C.E.C.) was determined using the cobaltihexamine method (Orsini and Rémy 1976). The plant available $\mathrm{P}$ was determined using the Olsen procedure (Olsen et al. 1954) and soil texture using granulometric analysis of five fractions without decarbonation.

\section{Species Traits}

Plant trait data were retrieved from the CLO-PLA3 database (Klimešová and Klimeš 2006) for a total of 111 species occurring in field layer vegetation. 
Species in the shrub layer belonging to the genera Salix spp. and Juniperus communis were not part of the analysis because there were no clonality data for these species. For 70 species, records in CLO-PLA3 were from our own collections in the study area conducted in 2003. For 36 species we retrieved records in CLO-PLA3 selecting those that corresponded to the most similar habitat when more than one record was available. For the remaining six species, clonal traits were derived from detailed illustrations in the Norwegian flora (Nordhagen 1979). A total of 43 traits class-attribute combinations were included in the study (see Table 1 for a description).

\section{Plant Assemblage Average Trait Composition}

Two matrices were constructed; a matrix of site by species abundance data and a matrix of species by trait attribute data. The trait classifications and their attributes used in the analyses are listed in Table 1. Species abundances were standardized; the summed cover of vascular plants for each site was $100 \%$. The site by species abundance matrix was multiplied with the species by trait attribute matrix, and the site average trait composition was calculated (cf. Pakeman 2004) according to the equation:

Average trait value for site ${ }_{j}=\Sigma\left(\mathrm{c}_{i} * \mathrm{t}_{i}\right) / \mathrm{C}_{j}$

Where $\quad \mathrm{C}_{j}=\Sigma \mathrm{c}_{i}$

$\mathrm{c}_{i}=$ the average cover of species $i$ in site $j$

$\mathrm{t}_{i}=$ the presence/absence $(1,0)$ of the nominal trait class for species $i$.

For species with more than one attribute within a trait class, each trait was weighted independently with the species cover. For example, Campanula rotundifolia had three types of CGO, epigeogenous stems, adventitious buds on roots and hypogeneous stems. Each type was weighted by the cover of $C$. rotundifolia in each plot.

\section{Environmental Data}

We conducted a principal component analysis (PCA) to determine the main patterns of the soil's physical and chemical property variation in the sites (Fig. 1a). Soil-PCA axis I explained ca $75 \%$ of the variance (eigenvalues of 0.774 and 0.177 for axis I and II, respectively) and was related to the composition of soil fractions and nutrients. Soil-PCA axis I corresponded to a gradient of increasing environmental harshness. Low scores on axis I corresponded to higher levels of fine soil particle fractions, lower $\mathrm{C} / \mathrm{N}$ ratio, higher content of $\mathrm{CaCO}_{3}$, and exchangeable $\mathrm{Ca}$ and $\mathrm{Mn}$. High scores on axis II were related to high organic matter and organic N and P. Because the Soil-PCA axis I explained most of the variation in soil properties among plots and the eigenvalue of axis II was relatively small as compared to axis I, we focused further analyses on Soil-PCA axis I, which we interpreted as a complex gradient of soil texture and chemistry that can be related to the availability of nutrients for plants. 
Table 1 Trait classes and their attributes used in the trait-wise ordinations. CGO - Type of clonal growth organ, according to the position of the organ (above-, at- and below the soil surface), and their origin (stem, root or leaf); necessary - plants that require the CGO for survival or, additive - plants where CGOs can be initiated by the conditions in the environment. Bud bank - position of the buds (Layer: $0=$ at soil surface, $>0$ above ground and $<0$ below ground), number of buds, and life cycle type - whether the bud bank has seasonal fluctuations (seasonal) or if buds are kept dormant (perennial). Integration - persistence of connection between parent and offspring shoots: 1 year (first season), 1-2 years, >2 years; and lateral spread - distance covered by lateral spreads in one year, in meters (CLO-PLA3, Klimešová and Klimeš 2006). Nr. of species - number of species in the data set with the trait class-attribute combination

\section{$\mathrm{CGO}$}

Code

Bulb-Tub

Type

Bulbs A

Bulbils and tubers

Bulbs N Bulbs

E-gen sA

Epigeogenous stems

E-gen sN Epigeogenous stems

H-gen sA

Hypogeogenous stems

H-gen sN

Hypogeogenous stems

Plantlet Plantlets

R-stem A Rooting horizontal stems

R-stem N Rooting horizontal stems

Rsplit A Root-splitters

Rsplit N Root-splitters

Rsplit $0 \quad$ Root-splitters

S-tub A Stem tubers

S-tub N Stem tubers

R-tube N Root tubers below-ground
N/A

additive

necessary

additive

necessary

additive

necessary

additive

additive

necessary

additive

necessary

none

additive

necessary

necessary
Nr. of species

2

1

2

4

67

2

30

2

2

7

3

1

8

1

Bud bank

Layer

1Bud0

Bud numbers in Layer $>10 \mathrm{~cm}$

1Bud1P

Bud numbers in Layer $>10 \mathrm{~cm}$

1 Bud1S

Bud numbers in Layer $>10 \mathrm{~cm}$

1Bud2P

Bud numbers in Layer $>10 \mathrm{~cm}$

$1 \mathrm{Bud} 2 \mathrm{~S}$

Bud numbers in Layer $>10 \mathrm{~cm}$

2Bud0

Bud numbers in Layer 0 to $10 \mathrm{~cm}$

2Bud1P

Bud numbers in Layer 0 to $10 \mathrm{~cm}$

2Bud1S

Bud numbers in Layer 0 to $10 \mathrm{~cm}$

2Bud2P

Bud numbers in Layer 0 to $10 \mathrm{~cm}$

2Bud2S

Bud numbers in Layer 0 to $10 \mathrm{~cm}$

3 Bud0

Bud numbers in Layer $0 \mathrm{~cm}$

3Bud1P

Bud numbers in Layer $0 \mathrm{~cm}$

3Bud1S

Bud numbers in Layer $0 \mathrm{~cm}$

3Bud2P

Bud numbers in Layer $0 \mathrm{~cm}$

3Bud2S

Bud numbers in Layer $0 \mathrm{~cm}$

4Bud0
No of buds

Life cycle type

No buds

$1-10$ buds

perennial

4

$1-10$ buds

seasonal

24

$>10$ buds

$>10$ buds

perennial

seasonal

No buds

1-10 buds

perennial

1-10 buds

seasonal

$>10$ buds

$>10$ buds

perennial

seasonal

No buds

1-10 buds

perennial

1-10 buds

seasonal

54

$>10$ buds

perennial

$>10$ buds

seasonal 
Table 1 (continued)

\begin{tabular}{lllll}
\hline 4Bud1P & Bud numbers in Layer 0 to $-10 \mathrm{~cm}$ & $1-10$ buds & perennial & 6 \\
4Bud1S & Bud numbers in Layer 0 to $-10 \mathrm{~cm}$ & $1-10$ buds & seasonal & 8 \\
4Bud2P & Bud numbers in Layer 0 to $-10 \mathrm{~cm}$ & $>10$ buds & perennial & 86 \\
4Bud2S & Bud numbers in Layer 0 to $-10 \mathrm{~cm}$ & $>10$ buds & seasonal & 1
\end{tabular}

Integration

$\begin{array}{ll}\text { Code } & \text { Type } \\ \text { P-C 1 } & \text { Persistence of connection } \\ \text { P-C 2 } & \text { Persistence of connection } \\ \text { P-C max } & \text { Persistence of connection } \\ \text { L-S 1 } & \text { Lateral spread } \\ \text { L-S } 2 & \text { Lateral spread } \\ \text { L-S } 3 & \text { Lateral spread } \\ \text { L-S } 4 & \text { Lateral spread }\end{array}$

\begin{tabular}{ll}
\multicolumn{1}{c}{ Value } \\
1 year & 7 \\
$1-2$ years & 6 \\
$>2$ years & 98 \\
$<0.01 \mathrm{~m} / \mathrm{yr}$ & 75 \\
$0.01-0.25 \mathrm{~m} / \mathrm{yr}$ & 41 \\
$>0.25 \mathrm{~m} / \mathrm{yr}$ & 1 \\
dispersable & 3
\end{tabular}

\section{Statistical Analysis}

We extracted three principal components of variation among sites in terms of the composition of $i$ ) clonal growth organs (CGO), ii) the bud bank and iii) traits related to "spread potential", namely lateral spread and the persistence of connections between plant and offspring (Table 1) by conducting three PCA ordinations based on the average trait composition in each site. Bud bank site averages were square root transformed after the inspection of a preliminary set of results showing a considerable improvement of the explanatory power of the PCA axes with the transformation. The analyses were conducted in CANOCO 4.5 (ter Braak and Šmilauer 2002) and ordination diagrams were produced with the CanoDraw module in the package.

To examine the relationships between persistence traits and traits related to relative growth rate and competitive ability, the site scores along axis I in the CGO-, bud bankand lateral spread-PCAs were regressed on the site aggregated traits (SLA, LDMC, leaf size and plant height calculated in Rusch et al. 2009). The type of the response, $R^{2}$ values and ANOVA tests of probabilities of significance were calculated with the regression curve-fit routine in SPSS v. 15.0 package for Windows.

\section{Results}

\section{Clonal Growth Organs}

All species in the data set (112) except one, Euphrasia wettsteinii (an annual species) have some potential for clonal reproduction. CGO-PCA axes I and II explained $95.8 \%$ of the variation in the CGO composition of the sites (eigenvalues $=0.877$ and 0.081 for axis I and II, respectively) (Fig. 1b). In sites with high scores on CGOPCA-I there was a predominance of rhizomes (both epigenous and hypogenous stems), whereas low scores were associated with a variety of clonal organs (root 
Fig. 1 Variable and site ordination diagrams on principal component (PCA) axis 1 and 2. Berg and Bat sites in Berghøgda and Båttjønndalen areas, respectively. a Soil variables: Coar_san, Fine_sil, Coar_sil, Fine_san and Clay - percentage of coarse sand, fine silt, coarse silt, fine sand and clay, respectively; Exch_Fe, Exch_Al, Exch_Mg, Exch_Na, Exch_Mn and Exch_Ca - exchangable cations (cmol/ $/ \mathrm{kg})$; Orga_mat, Wate_con and $\mathrm{W} H \mathrm{HC}$ - percentage organic matter and water content, and water holding capacity; $\mathrm{C}, \mathrm{N}$ and $\mathrm{CaCO}_{3}-$ total carbon, nitrogen and calcium carbonate (in $\mathrm{g} / \mathrm{kg}$ ), respectively; $\mathrm{P}$ - total P (P205) (g/100 g); $\mathrm{P}_{-}-\mathrm{P}(\mathrm{P} 205)$ by Olsen extraction (in ppm); C/N - Carbon:Nitrogen ratio. b, $\mathbf{c}$ and $\mathbf{d}$ 'Clonal growth organ' (CGO), 'bud bank' and 'integration' traits and attributes as described in Table 1, respectively

tubers, bulbs and stem tubers). Scores on CGO-PCA-I were significantly associated with the soil properties gradient (Soil-PCA-I) (Table 2) indicating that the distribution of CGOs in the sites was associated with site differences in soil properties.

In accordance with our hypotheses, we found a close correspondence between CGO-PCA axis I and LDMC, leaf size and plant height, but we found no significant association with SLA (Fig. 2 and Table 2). Site average LDMC increased, and average leaf size and plant height decreased in sites with a predominance of belowground stems.

\section{Bud Bank}

Bud bank-PCA axes I and II explained $81.3 \%$ of the variation in the bud bank composition of the sites (eigenvalues $=0.684$ and 0.129 for axis I and II, respectively) (Fig. 1c). Sites with low scores on the first axis had a predominance of seasonal bud banks, and the absence of buds at the soil surface and below ground. In contrast, sites with high scores on Bud bank-PCA-I had a predominance of perennial bud banks located at the soil surface, below-ground, and not higher than $10 \mathrm{~cm}$. Scores on Bud bank-PCA-I were significantly associated with the soil properties gradient (Soil-PCA-I) (Table 2) indicating that the distribution of bud bank traits among sites was in part associated with the site's soil properties.

Also in the case of the bud bank, we found a close correspondence and in the directions predicted between Bud bank-PCA-I and site average LDMC, leaf size and plant height, but there was no significant association with average SLA (Fig. 2 and Table 2). Site average LDMC increased, and that of leaf size and plant height decreased with high Bud bank-PCA-I scores, which represented a gradient from seasonal to perennial bud banks.

\section{Lateral Spread and Longevity of Plant-Offspring Integration}

Integration-PCA axes I and II explained $98.5 \%$ of the variation in the composition of the traits lateral spread (one of three classes of lateral spread distance, in meters) and persistence of connection ( 1,2 or $>2$ years) of the sites (eigenvalues $=0.747$ and 0.239 for axis I and II, respectively) (Fig. 1d). Low scores on axis I corresponded with high rates of lateral spread and short persistence of plant-offspring connections. Scores on Integration-PCA-I were significantly associated with Soil-PCA-I (Table 2) indicating that also in this case, trait composition was associated with site differences in soil properties. 

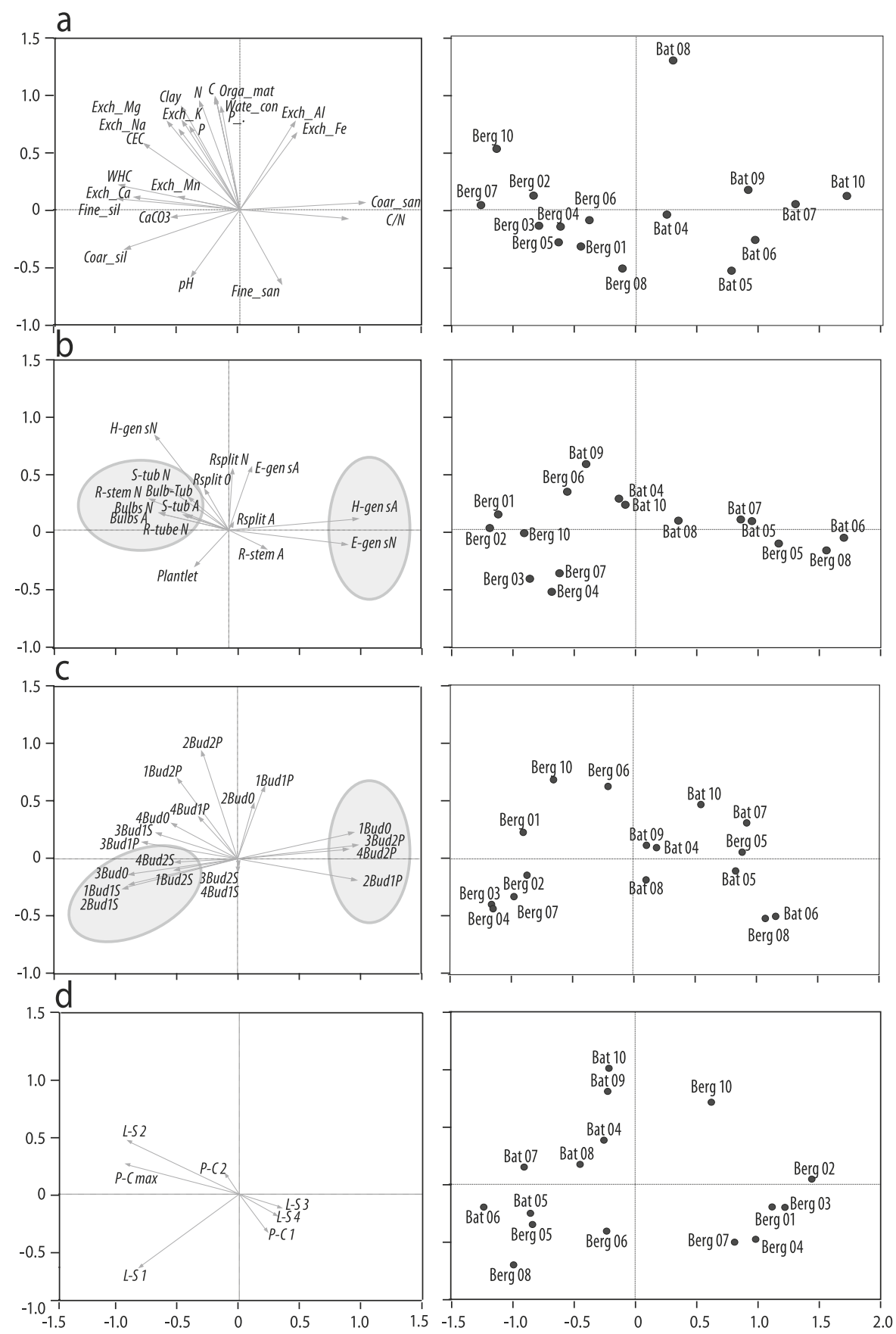
Table 2 Significance tests of regression analyses between site scores on traits' principal component analyses (PCA) axis 1, and on PCA axis 1 of soil properties and site average resource acquisition traits. Clonal growth and Integration classes and attributes as in Table 1. SLA - specific leaf area; LDMC - leaf dry matter content; leaf size, leaf area, including petioles, and plant height, mean range in Mossberg et al. (1992)

\begin{tabular}{lllll}
\hline CGO-PCA-I & Best fit model & $R^{2}$ & $F$ & $P$ \\
\hline Soil-PCA-I & Linear & 0.262 & 4.97 & 0.043 \\
SLA $\left(\mathrm{mm}^{2} / \mathrm{g}\right)$ & Quadratic & 0.299 & 0.26 & 0.099 \\
LDMC $(\mathrm{mg} / \mathrm{g})$ & Linear & 0.712 & 34.67 & 0.0001 \\
Leaf size $\left(\mathrm{mm}^{2}\right)$ & Linear & 0.544 & 16.69 & 0.001 \\
Plant height $(\mathrm{mm})$ & Linear & 0.733 & 38.48 & 0.0001
\end{tabular}

Bud bank-PCA-I

\begin{tabular}{|c|c|c|c|c|}
\hline Soil-PCA-I & Linear & 0.498 & 13.89 & 0.002 \\
\hline SLA $\left(\mathrm{mm}^{2} / \mathrm{g}\right)$ & Linear & 0.225 & 4.06 & 0.064 \\
\hline LDMC (mg/g) & Linear & 0.924 & 184.15 & 0.0001 \\
\hline Leaf size $\left(\mathrm{mm}^{2}\right)$ & Linear & 0.8 & 56.01 & 0.0001 \\
\hline Plant height (mm) & Linear & 0.883 & 105.95 & 0.0001 \\
\hline \multicolumn{5}{|l|}{ Integration-PCA-I } \\
\hline Soil-PCA-I & Linear & 0.436 & 10.81 & 0.005 \\
\hline SLA $\left(\mathrm{mm}^{2} / \mathrm{g}\right)$ & Linear & 0.154 & 2.55 & 0.13 \\
\hline LDMC (mg/g) & Linear & 0.8 & 57.57 & 0.0001 \\
\hline Leaf size $\left(\mathrm{mm}^{2}\right)$ & Linear & 0.81 & 13.22 & 0.001 \\
\hline Plant height (mm) & Linear & 0.97 & 403.69 & 0.0001 \\
\hline
\end{tabular}

We found a close correspondence between Integration-PCA axis I and LDMC, leaf size and plant height, but no significant association with SLA (Fig. 2 and Table 2). Site average LDMC decreased, and average leaf size and plant height increased in sites with high average lateral spread rates and low persistence of plantoffspring connections. Average plant height alone, explained ca. $90 \%$ of the variance of the traits distribution.

We tested the robustness of the analyses in terms of the extent to which the results could be affected by the dominance of one species in the assemblage. Three sites had a cover by Salix herbacea higher than $60 \%$ and the sites were strongly related to Soil- and traits PCA ordinations. Therefore, we conducted soil and clonal persistence ordinations, and the regression analyses of clonal against resource acquisition and competitive ability traits excluding these sites and we found the same response patterns and comparable significance levels for all the analyses (data not shown).

\section{Discussion}

The clonal and bud bank traits examined in the study changed their attributes along a gradient of soil properties, in accordance to our first hypothesis and further, they 

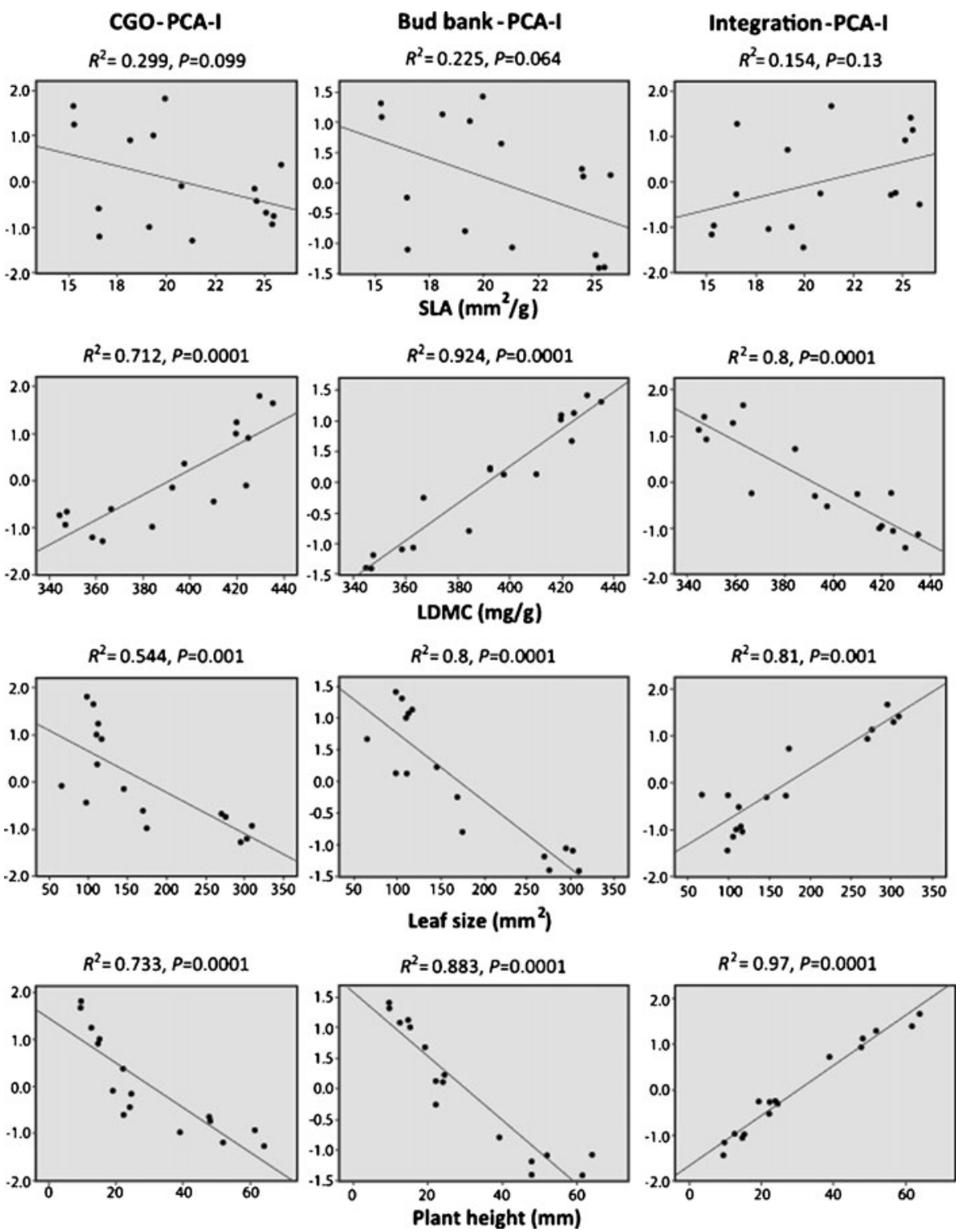

Fig. 2 Regression curves between site scores on trait principal component analyses (PCA) axis 1 and site average resource acquisition traits (as in Rusch et al. 2009). Clonal growth organ (CGO) and bud bank classes and attributes as in Table 1. SLA - specific leaf area; LDMC - leaf dry matter content; leaf size - leaf area (including petioles); and plant height - mean plant height range in Mossberg et al. (1992)

correlated with traits related to nutrient acquisition strategies, in agreement with our second hypothesis. These results imply that even when not fully recognized so far, clonal and bud bank traits contribute to syndromes of plant strategies along gradients of resource availability. 
Most species in the alpine communities in this study are clonal, which is common for herbaceous vegetation over temperate Europe. Further, in the arctic and alpine vegetation the overrepresentation of clonal forms has been explained as a strategy of plants to cope with harsh environments where vegetative reproduction is a mechanism to compensate for low seedling recruitment (Callaghan et al. 1992). It may also be the consequence of the dominance of small statured plants in this type of vegetation because clonal persistence appears to be a more widely spread strategy in plants of relatively small size (Aarssen 2008).

However, despite the widespread occurrence of clonal growth forms it was possible to distinguish differences in site CGO composition and there was a recognizable pattern that had a correspondence with site soil properties. Sites with soils with fine fractions, high cation exchange capacity and low C:N ratio were associated with a higher diversity of CGO, including rooting horizontal stems, root tubers, stem tubers and bulbs. At the other end of the gradient, the dominant CGOs were hypogenous and epigenous rhizomes (i.e., below-ground stems originating either below-ground or in the above-ground and pulled below the soil surface by contracting roots), which have the potential for carbon storage. Perennial rhizomes have been found to be associated with nutrient-poor environments in other alpine areas and wetlands (Klimeš 2008; Sosnová et al. 2010).

Clonal organs are important for the storage of nutrients (Chapin et al. 1990; Suzuki and Stuefer 1999; Derner and Briske 2001). However, the role of clonal organs is not only limited to the plant's nutrient economy in poor environments. Although the trade-off between costs and benefits of storage and remobilization of reserves is still inadequately understood, the capacity to store carbon appears to be generally important for the persistence of plants under environmental stress (Klimeš et al. 1993; Callaghan et al. 1997) although high amounts of stored carbohydrates might simply reflect surplus of carbon that is not used for growth due to nutrient limitations (Chapin et al. 1990).

We could also distinguish a gradient from sites where there is a predominance of plants with the capacity of long lateral spread and short persistence of connection between plant and clonal offspring (splitters sensu van Groenendael et al. 1996; restrictive integrators sensu Jónsdóttir and Watson 1997) at one extreme to sites with short lateral spread and long lasting connections (non-splitters sensu van Groenendael et al. 1996; extensive integrators sensu Jónsdóttir and Watson 1997) at the other. This gradient had a significant correspondence with the soil properties gradient; where increasing importance of splitters was associated with more favourable conditions for plant growth. Further, the association of the splittersintegrators gradient with the one of soil properties was stronger than in the case of CGOs. These results confirm our hypotheses and are in agreement with predictions about the benefits of integration under stressful environments (Jónsdóttir and Watson 1997) and also with findings from other alpine regions. In the Himalayas, Klimeš (2008) found an over-representation of integrators in nutrient-poor habitats and with increasing altitude, although most relationships between clonal integration and environmental factors could be explained by inter-species phylogenetic relationships, which suggests that clonal integration is an evolutionary conservative trait. In this study, a phylogenetic independent analysis was not feasible because the units of analysis were plant assemblages, and not species. The relative importance of 
phylogeny and environmental filters may be therefore difficult to establish. However, our results at the level of plant assemblages show a gradual variation in the composition of splitters and integrators along a gradient of soil properties. This pattern could be interpreted as the result of environmental filters operating locally on the regional flora (Lavorel and Garnier 2002) and determining, under the prevailing abiotic conditions for growth, varying success of species with particular sets of traits associated with the capacity to exploit productive and unproductive habitats (Grime 2006). This pattern, together with evidence about an adaptive trade-off between explorative and exploitive ramet placement (Thomas and Hay 2008) supports the idea of functional relationships between the forms of clonal reproduction and the physical environment.

Bud bank traits were also unevenly distributed among sites, and there was a pattern associated with the soil properties. Below-ground perennial bud banks were associated with nutrient poor substrate, and seasonal, above-ground bud banks were more represented in rich substrate sites. Several studies have addressed the question of bud banks in relation to responses of plants to disturbance (Benson et al. 2004; Klimešová and Klimeš 2007; Dalgleish and Hartnett 2009), but few have studied the relationships between bud banks and resource availability. In our study, it was not possible to assess whether bud bank densities varied with soil properties, but in agreement with patterns observed in other studies (Dalgleish and Hartnett 2006), we hypothesized that the capacity to sprout determined by the number of buds would be larger under more favorable conditions for growth. We found no distinguishable patterns regarding bud numbers along the soil properties gradient. In contrast, there were differences in the position (in height and depth) of traits associated to longevity/dormancy functions of the bud bank. Sites with fine-textured soils had a predominance of seasonal, above-ground bud banks whereas perennial, belowground banks occurred primarily in sites with coarse-textured soils. Perennial bud banks are associated with small within-year fluctuations in the number of buds, which contrasts with the dynamics of seasonal bud banks where at times (usually after spring re-growth) the number of buds can decrease considerably, resulting in larger fluctuations and, potentially, in meristem limitation in some periods of the year in the rich sites.

Recent reviews have stressed the need for integrated efforts in studying emerging properties of plant traits on lower hierarchical levels of the plant individual and their scaling up at higher organizational levels of the population, community and the entire ecosystem (Sammul et al. 2008). The analysis of clonal growth attributes at the scale of plant assemblages can make a contribution in this direction, because it is the relative composition and diversity (Wright et al. 2006) of traits associated with ecological functions that can be scaled up to predict ecosystem functions (Reich et al. 1992; Díaz and Cabido 2001; Garnier et al. 2007).

The examination of the relationships among traits with different ecological function, and of how these relationships are distributed along environmental gradients can also provide further insight about plant concerted strategies that enable persistence under the various conditions for growth (McGill et al. 2006). Grime et al. (1997) found that traits like root and shoot foraging were associated with foliar concentrations of $\mathrm{N}, \mathrm{P}, \mathrm{K}, \mathrm{Ca}$ and $\mathrm{Mg}$, the capacity for growth in productive conditions or the inability to sustain yield under limiting supplies of 
nutrients. However, despite the large body of empirical work conducted in the field of comparative ecology, both in the areas of clonality/vegetative reproduction and of plant traits related to resource acquisition and competitive ability (Jónsdóttir and Watson 1997; Bellingham and Sparrow 2000; Vesk and Westoby 2004), these groups of traits determining fundamental strategies of plant in response to the environment have seldom been analyzed together with the aim of exploring common patterns of trait distributions, largely due to the time-consuming effort of collecting below-ground traits for many species (Weiher et al. 1999), but see Wildová et al. (2007) and Goldberg et al. (2008).

The three groups of clonal growth traits analyzed in the study, namely the type of clonal growth organ, the degree of lateral spread and integration between parent plant and offspring, and the properties of the bud bank corresponded closely with traits associated with resource acquisition rates, competitive ability and protection against physical damage. Grime et al. (1997) postulated the existence of a fundamental axis of specialization in plants along the resource availability gradient that results from a trade-off between attributes that confer species an advantage when resources are in high supply (resource acquisition strategies), and those that are beneficial for plant performance in chronically poor environments (resource retention strategies). Evidence from numerous empirical and observational studies (Keddy and Shipley 1989; Goldberg 1996; Westoby 1998; Westoby et al. 2002) support the association between plant height and the species competitive ability when resources are in high supply, and between leaf traits (e.g., leaf area and LDMC, and SLA - although in this case, less consistent) and the amount of resources available for plant growth (Kazakou et al. 2006; Rusch et al. 2009). The distribution of clonal attributes also appears to vary along the resource availability axis (van Groenendael et al. 1996; Klimeš et al. 1997; Dalgleish and Hartnett 2006) although the amount of evidence is considerably smaller. Our results show patterns of clonal growth traits in correspondence with soil properties. They also show that clonal traits that are linked to plant growth and to attributes related to the plant's carbon and nutrient economy (Jónsdóttir and Watson 1997) had a close association with leaf traits (LDMC and area) and plant height. These observations reinforce the hypotheses about trade-offs between acquisition and retention strategies in plants. However, and contrary to our hypothesis, we found no correspondence between SLA, a trait generally considered to be tightly associated to the resource acquisition-retention axis, and the distribution of the clonal growth traits assessed in the study (CGO, bud bank and integration). This could be due to the lack of association of SLA in this data set with soil properties. Rusch et al. (2009) found a lack of correspondence of SLA with soil fertility that could be attributed to difficulties to accurately assess leaf area when leaves are narrow or small (Cornelissen et al. 2003); or to the dependence of the SLA index on species-specific morphological attributes (Vile et al. 2005) that may have opposing effects (Cunningham et al. 1999) when calculating community aggregated traits.

Acknowledgements The research was funded by the Research Council of Norway, Landskap i endring programme, and EU-INCO 6 FP : VISTA, Vulnerability of ecosystem services to land-use change in traditional agricultural landscapes and LEDA, A database on the life history of the Northwest European 
flora. Soil analyses were conducted by INRA, Toulouse, France. We thank the farmers of Hessdal grazing district, and the Fjellstyre i Sør-Trøndelag for allowing the use of the area; P. Skogaas for all forms of logistic support during the field work; C. Skarpe, E. Sætnan, E. Aarnes, and T. Flower-Ellis for assistance with data collection. JK was supported by the Grant Agency of the Czech Republic, grant GA526/07/0808 and grant AV 0Z60050516 from the Academy of Sciences of the Czech Republic. We thank Steinar Engen for fruitful discussion on linear regressions; and F de Bello and two anonymous referees for thoughtful comments that considerably helped to improve the paper.

Open Access This article is distributed under the terms of the Creative Commons Attribution Noncommercial License which permits any noncommercial use, distribution, and reproduction in any medium, provided the original author(s) and source are credited.

\section{References}

Aarssen LW (2008) Death without sex - the "problem of the small" and selection for reproductive economy in flowering plants. Evol Ecol 22:279-298

Afnor, Association française de normalisation (1994) Qualité des sols. La Défense, Paris

Bellingham PJ, Sparrow SD (2000) Resprouting as a life history strategy in woody plant communities. Oikos 89:409-416

Benson EJ, Hartnett DC, Mann KH (2004) Belowground bud banks and meristem limitation in tallgrass prairie plant populations. Amer J Bot 91:416-421

Callaghan TV, Carlsson BA, Jónsdóttir IS, Svensson BM, Jonasson S (1992) Clonal plants and environmental change. Oikos 63:341-453

Callaghan TV, Jonasson S, Brooker RW (1997) Arctic clonal plants and global change. In de Kroon H, Van Groenendael J (eds) The ecology and evolution of clonal plants. Backhuys Publishers, Leiden, pp 381-403

Chapin FS, Schulze ED, Mooney HA (1990) The ecology and economics of storage in plants. Annual Rev Ecol Syst 21:423-447

Cornelissen JHC, Lavorel S, Garnier E, Díaz S, Buchmann N, Gurvich D, Reich P, ter Steege H, Morgan H, van der Heijden M, Pausas J, Poorter H (2003) Handbook of protocols for standardised and easy measurement of plant functional traits worldwide. Austral J Bot 51:335-380

Cunningham S, Summerhayes B, Westoby M (1999) Evolutionary divergences in leaf structure and chemistry, comparing rainfall and soil nutrient gradients. Ecol Monogr 69:569-588

Dalgleish HJ, Hartnett DC (2006) Below-ground bud banks increase along a precipitation gradient of the North American Great Planins: a test of the meristem limitation hypothesis. New Phytol 171:81-89

Dalgleish HJ, Hartnett DC (2009) The effects of fire frequency and grazing on tallgrass prairie productivity and plant composition are mediated through bud bank demography. Pl Ecol 201:411-420

de Bello F, Lepš J, Sebastià MT (2005) Predictive value of plant traits to grazing along a climatic gradient in the Mediterranean. $J$ Appl Ecol 42:824-833

del-Val E, Crawley MJ (2005) Are grazing increaser species better tolerators than decreasers? An experimental assessment of defoliation tolerace in eight British grassland species. $J$ Ecol 93:1005-1016

Derner JD, Briske DD (2001) Below-ground carbon and nitrogen accumulation in perennial grasses: A comparison of caespitose and rhizomatous growth form. Plant \& Soil 237:117-127

Díaz S, Cabido M (2001) Vive la différence: plant functional diversity matters to ecosystem processes. Trends Ecol Evol 16:646-655

Ferraro DO, Oesterheld M (2002) Effect of defoliation on grass growth. A quantitative review. Oikos 98:125-133

Garnier E, Lavorel S, Ansquer P, Castro H, Cruz P, Dolezal J., Eriksson O, Fortunell C, Freitas H, Golodets C, Grigulis K, Jouany C, Kazakou E, Kigel J, Kleyer M, Lehsten V, Lepš J, Meier T, Pakeman RJ, Papadimitriou M, Papanastasis VP, Quested HM, Quétier F, Robson M, Roumet C, Rusch G, Skarpe C, Sternberg M, Theau J-P, Thébault A, Vile D, Zarovali MP (2007) Assessing the effects of land-use change on plant traits, communities and ecosystem functioning in grasslands: A standardized methodology and lessons from an application to 11 European sites. Ann Bot (Oxford) 99:967-985

Goldberg D.E. (1996) Competitive ability: Definitions, contingency and correlated traits. Philos Trans, Ser B 351:1377-1385 
Goldberg DE, Wildová R, Herben T (2008). Consistency vs. contingency of trait-performance linkages across taxa. Evol Ecol 22:477-481

Grime JP (2006) Trait convergence and trait divergence in herbaceous plant communities: Mechanisms and consequences. $J$ Veg Sci 17:255-260

Grime JP, Thompson K, Hunt R, Hodgson JG, Cornelissen JHC, Rorison IH, Hendry GAF, Ashenden TW, Askew AP, Band SR, Booth RE, Bossard CC, Campbell BD, Cooper JEL, Davison AW, Gupta PL, Hall W, Hand DW, Hannah MA, Hillier SH, Hodkinson DJ, Jalili A, Liu Z, Mackey JML, Matthews N, Mowforth MA, Neal AM, Reader RJ, Reiling K, RossFraser W, Spencer RE, Sutton F, Tasker DE, Thorpe PC, Whitehouse J (1997) Integrated screening validates primary axes of specialisation in plants. Oikos 79:259-281

Halassy M, Campetella G, Canullo R, Mucina L (2005) Pattens of functional clonal traits and clonal growth modes in contrasting grasslands in the central Apennines, Italy. J Veg Sci 16:29-36

Harper JL (1977) Population biology of plants. Academic Press, New York

Jónsdóttir IS, Watson MA (1997) Extensive physiological integration: an adaptive trait in resource-poor environments? In de Kroon H, van Groenendael JM (eds) The ecology and evolution of clonal plants. Backhuys Publishers, Leiden, pp109-136

Kazakou E, Vile D, Shipley B, Gallet C, Garnier E (2006) Co-variations in litter decomposition, leaf traits and plant growth in species from a Mediterranean old-field succession. Funct Ecol 20:21-30

Keddy PA, Shipley B (1989) Comparative hierarchies in herbaceous plant communities Oikos 54:234-241

Klimeš L (2008) Clonal splitters and integrators in harsh environments of the Trans-Himalaya. Evol Ecol 22:351-367

Klimeš L, Klimešová J, Osbornová J (1993) Regeneration capacity and carbohydrate reserves in a clonal plant Rumex alpinus - effect of burial. Vegetatio 109:153-160

Klimeš L, Klimešová J, Hendriks RJJ, van Groenendael JM (1997) Clonal plant architecture: A comparative analysis of form and function. In de Kroon H, van Groenendael JM (eds) The ecology and evolution of clonal plants. Backhuys Publishers, Leiden, pp 1-29

Klimešová J, de Bello F (2009) CLO-PLA: the database of clonal and bud bank traits of Central European flora. J Veg Sci 20:511-516

Klimešová J, Klimeš L (2006) CLO-PLA3 - a database of clonal growth of Central European flora. Pl Ecol 141:9-19

Klimešová J, Klimeš L (2007) Bud banks and their role in vegetative regeneration - A literature review and proposal for simple classification and assessment. Perspect Pl Ecol Evol Syst 8:115-129

Lavorel S, Garnier E (2002) Predicting changes in community composition and ecosystem functioning from plant traits: revisiting the Holy Grail. Funct Ecol 16:545-556

Lid J, Lid DT (2005) Norsk flora (Norwegian flora). Det Norske Samlaget, Oslo

McGill BJ, Enquist BJ, Weiher E, Westoby M (2006) Rebuilding community ecology from functional traits. Trends Ecol Evol 21:178-185

Mossberg B, Stenberg L, Ericsson S (1992) Den nordiska floran (The Nordic flora). Wahlström \& Widstrand, Stockholm

Nordhagen R (1979) Norsk flora: illustrasjonsbind (Norwegian flora: illustration). H. Aschelhoug \& Co. (W. Nygaard), Oslo

Olsen SR, Cole CV, Watanabe MFS, Dean LA (1954) Estimation of available phosphorus in soil by extraction with sodium bicarbonate. USDA Circular No. 939, US Govt. Print. Office, Washington, $\mathrm{DC}$

Orsini L, Rémy JC (1976) Utilisation du chlorure de cobaltihexamine pour la détermination simultanée de la capacité d'échange et des bases échangeables des sols. Bull Assoc Franç Etude Sol 4:269-279

Pakeman RJ (2004) Consistency of plant species and trait responses to grazing along a productivity gradient: a multi-site analysis. $J$ Ecol 92:893-905

Reich PB, Walters MB, Ellsworth DS (1992) Leaf life-span in relation to leaf, plant, and stand characteristics among diverse ecosystems. Ecol Monogr 62:365-392

Reich PB, Ellsworth DS, Walters MB, Vose JM, Gresham C, Volin JC, Bowman WD (1999) Generality of leaf trait relationships: A test across six biomes. Ecology 80:1955-1969

Rusch GM, Nygård T, Spörndli C, Gjershaug JO, Skarpe C (2003) Biologisk mangold i Forollhogna Nasjonalpark: Fjellet og sauen - og samspillet (Biodiversity in the Forollhogna National Park: Mountains, sheep - and their interactions). Villrein 2003:103-111

Rusch GM, Skarpe C, Halley D (2009) Plant traits link hypothesis about resouce-use and response to herbivory. Basic Appl Ecol 10:466-474

Ryser P, Urbas P (2000) Ecological significance of leaf life span among Central European grass species. Oikos 91:41-50 
Sammul M, Kull K, Tamm A (2003) Clonal growth in a species-rich grassland: results of a 20-year fertilization experiment. Folia Geobot 38:1-20

Sammul M, Kull T, Kull K, Novoplansky A (2008) Generality, specificity and diversity of clonal plant research. Evol Ecol 22:373-277

Sosnová M, van Diggelen R, Klimešová J (2010) Distribution of clonal growth forms in wetlands. Aquatic Bot 92:33-39

Suzuki JI, Stuefer JF (1999) On the ecological and evolutionary significance of storage in clonal plants. $P l$ Spec Biol 14:11-1

ter Braak CJF, Šmilauer P (2002) CANOCO Reference Manual and CanoDraw for Windows User's Guide, Software for Canonical Community Ordination (version 4.5). Biometris, Wageningen and České Budějovice

Thomas RG, Hay MJM (2008) Adaptive variation in physiological traits underpinning stem elongation responses among nodally-rooting stoloniferous herbs. Evol Ecol 22:369-381

Van Groenendael JM, Klimeš L, Klimešová J, Hendriks RJJ (1996) Comparative ecology of clonal plants. Philos Trans, Ser B 351:1331-1339

Vesk PA, Westoby M (2004) Sprouting ability across diverse disturbances and vegetation types worldwide. J Ecol 92:310-320

Vile D, Garnier E, Shipley B, Laurent G, Navas ML, Roumet C, Lavorel S, Díaz S, Hodgson JG, Lloret F, Midgley GF, Poorter H, Rutherford MC, Wilson PJ, Wright IJ (2005) Specific leaf area and dry matter content estimate thickness in laminar leaves. Ann Bot (Oxford) 96:1129-1136

Weiher E, van der Werf A, Thompson K, Roderick M, Garnier E, Eriksson O (1999) Challenging Theophrastus: A common core list of plant traits for functional ecology. J Veg Sci 10:609-620

Westoby M (1998) A leaf-height-seed (LHS) plant ecology strategy scheme. Plant \& Soil 199:213-227

Westoby M, Falster DS, Moles AT, Vesk PA, Wright IJ (2002) Plant ecological strategies: Some leading dimensions of variation between species. Annual Rev Ecol Syst 33:125-159

Wildová R, Gough L, Herben T, Hershock C, Goldberg DE (2007) Architectural and growth traits differ in effects on performance of clonal plants: an analysis using a field-parametrized simulation model. Oikos 116:836-852

Wise MJ, Abrahamson WG (2005) Beyond the compensatory continuum: environmental resource levels and plant tolerance of herbivory. Oikos 109:417-428

Wright IJ, Westoby M (1999) Differences in seedling growth behaviour among species: trait correlations across species, and trait shifts along nutrient compared to rainfall gradients. $J$ Ecol 87:85-97

Wright JP, Naeem S, Hector A, Lehman C, Reich PB, Schmid B, Tilman D (2006) Conventional functional classification schemes underestimate the relationship with ecosystem functioning. Ecol Lett 9:111-120

Received: 17 April 2009 / Revised: 11 March 2010 / Accepted: 29 March 2010 /

Published online: 15 September 2010

\section{Appendix 1 List of Species Recorded in the Study}

Aconitum lycoctonum, Agrostis mertensii, Alchemilla alpina, Alchemilla glabra, Alchemilla glomerulans, Andromeda polifolia, Antennaria dioica, Anthoxanthum nipponicum, Arctostaphylos uva-ursi, Arctous alpinus, Athyrium distentifolium, Avenella flexuosa, Bartsia alpina, Betula nana, Betula pubescens subsp. tortuosa, Bistorta vivipara, Calluna vulgaris, Campanula rotundifolia, Carex atrata, Carex atrofusca, Carex bigelowii, Carex nigra var. nigra, Carex norvegica coll., Carex panicea, Carex saxatilis, Cerastium alpinum, Cerastium cerastoides, Cerastium fontanum subsp. fontanum, Coeloglossum viride, Deschampsia cespitosa, Diapensia lapponica, Dryas octopetala, Empetrum nigrum subsp. hermaphroditum, Epilobium anagallidifolium, Equisetum arvense subsp. boreale, Equisetum hyemale, Erigeron borealis, Erigeron uniflorus subsp. uniflorus, Eriophorum angustifolium subsp. angustifolium, Eriophorum vaginatum, Festuca ovina, Festuca rubra, Geranium sylvaticum, Geum rivale, Hieracium alpinum agg., Huperzia appressa, Juncus castaneus, Juncus filiformis, Juncus trifidus, Leontodon autumnalis, Loiseleuria procumbens, Luzula multiflora subsp. frigida, Luzula spicata, Luzula sudetica, Lycopodium clavatum subsp. monostachyon, Nardus stricta, Omalotheca norvegica, Omalotheca supina, Oxyria digyna, Parnassia palustris, Pedicularis lapponica, Pedicularis oederi, Petasites frigidus, Phleum alpinum, Phyllodoce caerulea, Pinguicula vulgaris, Plantago major, Poa alpina, Potentilla crantzii, 
Potentilla erecta, Pyrola minor, Pyrola norvegica, Ranunculus acris subsp. pumilus, Ranunculus pygmaeus, Rhodiola rosea, Rubus chamaemorus, Rumex acetosa subsp. lapponicus, Salix herbacea, Salix polaris, Salix reticulata, Saussurea alpina, Saxifraga aizoides, Saxifraga oppositifolia, Saxifraga stellaris, Selaginella selaginoides, Sibbaldia procumbens, Silene acaulis, Silene dioica, Solidago virgaurea, Succisa pratensis, Taraxacum croceum agg., Thalictrum alpinum, Tofieldia pusilla, Trichophorum cespitosum subsp. cespitosum, Trientalis europaea, Trisetum spicatum, Vaccinium myrtillus, Vaccinium uliginosum, Vaccinium vitis-idaea, Veronica alpina, Veronica serpyllifolia subsp. serpyllifolia, Viola biflora, Viola palustris 